\title{
17 Guidelines for best practice in great ape tourism
}

\author{
Elizabeth A. Williamson and Elizabeth J. Macfie
}

\section{Introduction}

Tourism based on the viewing of great apes is increasingly promoted as a means of generating revenue for range states, local communities, and the private sector (e.g. GRASP, 2006). This is despite known risks from tourism, including disease transmission, which have caused concern among conservationists and prompted the International Union for Conservation of Nature to publish guidelines on best practices for great ape tourism (Macfie \& Williamson, 2010). IUCN is one of the world's most respected authorities on species conservation, and brings together governments, UN agencies, and NGOs to conserve biodiversity and to ensure that any use of natural resources is equitable and ecologically sustainable.

Great apes are of high conservation concern because all species and subspecies are listed as Endangered or Critically Endangered (IUCN, 2013) and are protected throughout their range by both national and international laws. They are particularly appealing to human observers because they are behaviorally and physically so similar to people. However, their genetic closeness also makes great apes susceptible to human diseases for which they have no immunity (in this volume, see chapters by Dellatore et al $_{\mathbf{2}}$ Desmond \& Desmond $\overline{\mathbf{2}}_{\mathbf{2}}$ Goldsmith $_{\overline{\mathbf{2}}}$ Muehlenbein \& Wallis, Russon et at.).

Tourism regulations specific to great apes were first developed with the advent of mountain gorilla tourism in the 1970s (Weber, 1993). These were initially based on intuition and common sense, but have been adapted and revised over time on the basis of field experience and impact studies and subjected to scientific review (Homsy, 1999). Mountain gorilla tourism has enabled improved monitoring and protection of habituated gorilla groups, enhanced the profile of great apes at both national and international levels, and helped improve the livelihoods of local communities (Blomley et al., 2010; Gray \& Rutagarama, 2011; Plumptre \& Williamson, 2001; Robbins et al. 2011; Williamson \& Fawcett, 2008). However, tourism also creates risks to the great apes visited, notably stress and disease transfer (Palacios et al., 2011), making it important to institute measures to minimize these risks by controlling the conditions of visits, such as their frequency and duration, the distance to be maintained between apes and observers, and the health and number of visitors per group (Homsy, 1999; Ryan \& Walsh, 2011). To this end, IUCN

Primate Tourism: A Tool for Conservation?, eds. Anne E. Russon and Janette Wallis. Published by Cambridge University Press. (C) Cambridge University Press 2014. 
developed best practice guidelines for great ape tourism through the collaborative and consensual input of many experts. These guidelines aim to establish and promote international standards, increase awareness of appropriate conservation practices, decrease likelihood of practices and projects that are wrong or harmful, and inform and support sound policy decisions relating to the protection and management of great apes and their habitat.

For great ape tourism to contribute to the conservation of great apes and their habitats, these guidelines must be rigorously applied and tourism activities strictly controlled. In this chapter we summarize IUCN guidelines, focusing on their recommendations for tourism implementation, monitoring and evaluation, and visitation "rules." We also present nine guiding principles for using tourism as a great ape conservation tool(Macfie \& Williamsen, 2010). The IUCN publication additionally includes a history of 30 years of great ape tourism, a review of lessons learned, potential impacts (key positive and critical negative), clear recommendations as to when tourism with apes is and is not appropriate, guidance in the planning and development of tourism initiatives, and great ape species-specific guidelines.

\section{Visit regulations}

Individual great ape tourism sites should develop detailed regulations incorporating lessons learned from other sites, and should monitor, reinforce, and improve these regulations throughout the lifespan of their program. Site-specific regulations should be developed in consultation with specialists in medicine, ecology, biolegy, and behavior, as well as travel and tourism practitioners (Muehlenbein \& Ancrenaz, 2009). However, good plans are meaningless without effective enforcement, and poor enforcement has been a perennial problem for great ape tourism (e.g. Sandbrook \& Semple, 2006). Therefore, it is critical that conservation managers have the authority to institute tourism regulations, to exercise authority once tourism is underway, and to maintain that authority over the long term. This will help to foster compliance by both staff and tourists.

Ideally, all visitors should be informed of the rationale behind the measures instituted to minimize disease risks and other negative impacts of tourism, both during the booking process and again prior to their arrival at a great ape tourism site. Printed regulations should be sent to tour operators, marketing, or booking agents and, if possible, posted on a website.

The general regulations given below are relevant to most great ape tourism sites.

\section{Presentation of tourism impacts and safety issues upon arrival}

Site authorities should provide appropriate information on the various impacts of tourism on great apes when the tourists arrive. Presentation should be thorough and consist of both active discussion of the regulations that minimize risks and 
passive information transfer (such as written materials in accommodation facilities and displays and signage in check-in areas). To better prepare all visitors, this can be reinforced with demonstrations of the required safe distance and role play with guides on how to respond to an approaching ape. Tourists will be more likely to remember and enact what they have been taught if they have practiced acting it out. Safety precautions should also be explained at this time and, if required by local regulations, all visitors should sign liability waivers.

\section{Immunization requirements}

Many great ape sites require that tourists present proof of vaccination and/or a current negative test for a number of diseases. Vaccination requirements may include polio, tetanus, measles, mumps, rubella, hepatitis A and B, yellow fever, meningococcal meningitis, typhoid, and tuberculosis. For tuberculosis, proof of a negative skin test within the last six months may be acceptable. The immunization requirement has a number of advantages beyond preventing the spread of these diseases. It reinforces the visitor's perception that tourism poses a risk to the apes. Awareness of this risk should also stimulate any responsible tourist's willingness to adhere to guidelines for their visit, including self-reporting potential medical conditions and volunteering not to visit.

While vaccination requirements may stimulate awareness of the disease risks and control some potential infections, proof of vaccination or a negative test alone will not control all infections of concern, such as the common cold and influenza, for which there is either no vaccine or vaccines for certain strains only. Neither will it guarantee tourists' compliance with health regulations. Vaccinated tourists may develop a false sense of security and feel that they can violate other regulations because they are immunized. In addition, lead-times for vaccination mean that vaccination requirements may not be easy to manage when tourists arrive (e.g. vaccinating only one day before a visit is generally not protective, and a modified live vaccine may infect other contacts, apes included). To avoid visitor disappointment and enhance compliance, vaccination and health regulations should be provided at the time of booking and should be widely available on websites providing booking information, so that tourists can arrange for any immunizations or tests required and obtain the necessary documentation before traveling.

\section{Guided health evaluation prior to departure}

During final check-in for a tourist visit, staff should inspect vaccination certificates rather than rely on self-reporting (Muehlenbein et al., 2008). Self-evaluation will identify those willing to decline a visit on health grounds and facilitate the process of refunding tourists who self-report illness, but does not ensure compliance because some tourists will try to conceal symptoms. 
Tourists should then be guided through a self-evaluation designed to highlight whether they might be infectious or otherwise unable to participate in the visit. This should include a checklist of symptoms such as sneezing, coughing, fever, or diarrhea within the previous 48 hours, and exposure to any significant risks (e.g. disease, bat caves). Bats are thought to carry Marburg virus (Timen et al., 2009) and several species of fruit bat have been implicated in the complex transmission cycles of Ebola virus (Leroy, 2005); both of these hemorrhagic diseases are highly lethal to great apes and humans, so tourist visits to bat caves or roosts should be scheduled after viewing great apes or avoided altogether in countries with a history of Marburg or Ebola.

\section{Professional health evaluation}

An on-site health professional could perform routine health checks, such as measuring body temperature, heart rate, and respiratory rate. This will not be possible at all sites, but large tourism programs should consider having a nurse or doctor on the staff along with employee health programs. Health professionals will also be able to advise on local and global disease patterns and propose additional precautions as needed. Guides should also be trained to recognize tourists who are unwell and given authority to exclude them from great ape tourism activities.

\section{"The rules"}

Despite strict enforcement of vaccination and other preventive health measures outlined above, tourists who have traveled long distances (usually at great expense) may try to hide illness and some could be infectious without knowing it or carry infections that health checks fail to detect. Consequently, everyone who approaches great apes poses a potential disease risk and must be required to behave accordingly. Strict regulations are also important to minimize the behavioral impacts of tourist visits. Any site claiming that they adhere to Best Practice in great ape tourism must implement the following:

\section{No visits by people who are sick}

People who are unwell will not be allowed to visit the apes. This must be made very clear at the time of booking. It is critical to encourage tourists to self-report their illnesses and offer incentives to refrain from visiting if necessary. Incentives should not include a postponed visit (it is probable that the person would continue to be infectious for a few days), but could be a refund on-site or vouchers for other tourism services (e.g. accommodation, hiking). Similarly, staff members who are ill must not participate in ape visits and must be given incentives to remain away from apes, such as guaranteed "sick days" and a policy of non-discrimination if they cannot work because of illness. 


\section{Children younger than 15 years old prohibited from visiting}

Children under 15 years old must not be allowed to visit great apes. This safeguard is primarily for health reasons. Young people are more likely to be infected with common childhood diseases, even when properly vaccinated, and therefore pose a much greater health risk to habituated apes.

\section{One tourist visit per day of limited duration}

There should be no more than one visit per day to each group of apes (or individual/ party/forest area in the case of chimpanzee and orangutan tourism) with a maximum duration of one hour (see "One-hour time limit" below). Any existing site that has been operating more than one visit per day should reduce the schedule to one visit a day per group or individual. This can be done by closing second-visit bookings over time, or in some cases by habituating a new group. New groups should be habituated only if a full impact assessment indicates the conservation benefits will outweigh the costs. In addition, tourism accommodation located in or near ape habitat must limit visitor movements away from the facility to prevent uncentrolled ape viewing.

\section{Maximum number of tourists per group}

To minimize behavioral disturbance and disease risk, strict limits on the number of tourists allowed to visit each day must be set and adhered to. In dense forest where visibility is poor, any sudden noise or movement could cause alarm and unpredictable reactions. In addition, finding a good viewing spot for each tourist can be challenging. Tourists must stay together and avoid encircling the apes being viewed. To facilitate the control of visitors, minimize danger, and enhance visitor satisfaction, the number of people per party should be no more than four tourists accompanied by two guides/trackers. This should achieve a reasonable balance between apes and humans, and reduce behavioral disturbance, stress, and their associated effects. Small numbers also favor high permit prices, as tourists tend to value being part of a small and exclusive group of visitors.

This general guideline should be implemented at all new sites. Species-specific recommendations on tourist numbers are discussed in Macfie and Williamson (2010). A few sites currently operate with less than four tourists per visiting group and their success suggests that numbers can and should remain low at these sites. Mountain gorilla sites and some chimpanzee sites currently operate with more than four tourists, and these sites should assess whether reducing tourist numbers toward this recommended maximum of four could be feasible in future. Any new ape groups opened for tourism should have a smaller number of tourists.

\section{N95 respirator masks}

All tourists and staff who are likely to approach habituated apes to within $10 \mathrm{~m}$ should wear a surgical quality N95 respirator mask for the duration of their one- 


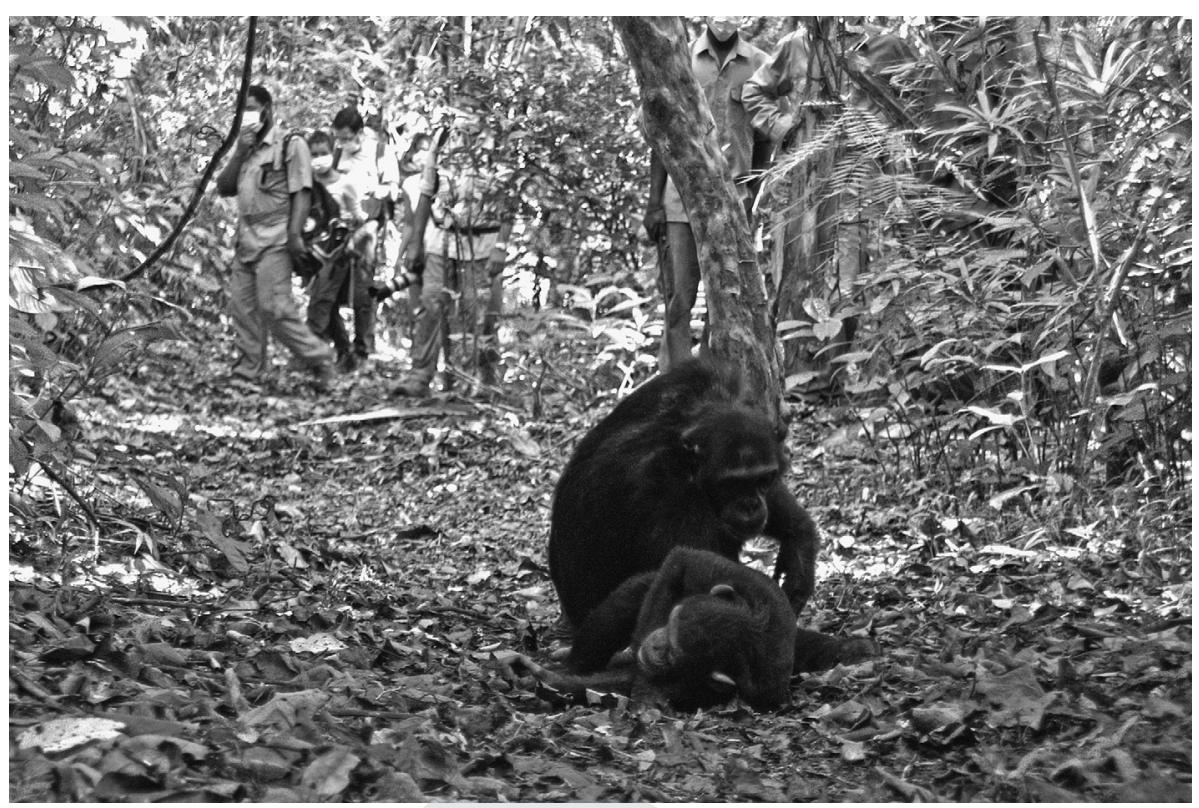

Figure 17.1. Tourists wearing face masks while viewing chimpanzees in Mahale Mountains National Park (C) Toshisada Nishida, Tanzania)

hour visit (Figure 17 1). Respirators that filter out higher percentages of aerosolized particles are also acceptable (i.e. N99 or N100). Masks should be carried by trackers/guides in appropriate waterproof containers so that they are not damaged and rendered less effective during transport. They should be distributed to tourists just before they begin actually viewing the apes and collected for appropriate disposal afterwards.

A surgical mask should give the wearer a false sense of security regarding the risks they pose while in proximity to apes- ${ }_{-1} 11$ other regulations (concerning hygiene, distance from the apes, visit duration) must be enforced alongside mask use. Appropriate education in hygiene must be given to staff and tourists alike. Tourists feeling the urge to sneeze or cough while in proximity to the apes should turn their head away even when wearing a surgical mask, but should not remove the mask; if the mask worn becomes soiled or damp, however, staff should offer a replacement mask.

Masks are disposable and should not be re-used. They should be collected by the trackers/guides immediately after the visit and disposed of appropriately after the visit, as they pose a disease risk to apes and other wildlife if accidentally dropped or otherwise disposed of in the forest. Masks must be burned upon return to tourism administration or accommodation facilities, away from areas where apes range.

Staff must receive training in mask management, including proper fit-testing, wear, use, and disposal. Trained staff should demonstrate appropriate mask use in full to tourists at the visit departure point and review this before they reach the 10-m distance from any apes, so that masks are not put on incorrectly in a rush to 
see the apes. Masks that become damp or wet are less effective at blocking pathogens and should be exchanged for a new one.

Mask management should be monitored as part of a broader tourism monitoring program, and results used to inform and improve procedures. Tourist compliance and feedback should also be taken into consideration when reviewing mask management procedures.

Procurement systems must ensure a reliable supply of appropriate masks on site. If N95 respirator masks are not available, surgical quality multi-layer masks may be used until N95 respirators are procured because they provide a barrier to large droplets. Their use should be temporary because they are less effective in preventing disease transmission than $\mathrm{N} 95$ respirators.

\section{Minimum distance to habituated great apes}

The minimum distance to which visitors wearing N95 surgical masks are permitted to approach great apes is $7 \mathrm{~m}$. For visitors not wearing N95 masks, the minimum distance permitted is $10 \mathrm{~m}$ (see also Klailova ${ }_{\mathbf{2}}$ Hodgkinsen, \& Lee, 2010).

\section{One-hour time limit}

Tourist visits must be restricted to no more than one hour. This limit, combined with the restriction of one visit per day, should ensure that no ape is visited by tourists for more than one hour on any day. If apes are not easily visible when first approached, staff should escort tourists away to a distance of $200 \mathrm{~m}$ to await a time when the apes are resting or have moved into more open vegetation, and then begin the permitted hour.

\section{Non-essential personnel to remain at a distance from apes}

Non-essential personnel such as military escorts or porters must stay as far away from the apes as feasible during tourist visits, out of sight and earshot. Such personnel should remain in contact with guides via walkie-talkie radios so that they can be instructed to move if the apes start moving in their direction.

\section{Hand-washing and hygiene}

Basin facilities and soap should be provided at departure points and tourists encouraged to wash their hands before departure. Additionally, guides should carry hand disinfectant spray (such as chlorhexidine), gel, or wipes for all visitors and staff to use before approaching apes.

Latrines must be provided at departure points and tourists encouraged to use them before departure. Latrines should be constructed at appropriate distances from watercourses (at least $30 \mathrm{~m}$ ). If tourists or staff need to urinate or defecate while in the forest, they should do so at least $500 \mathrm{~m}$ away from apes and watercourses and feces must be buried in a 30-cm deep hole. 
Smoking is not permitted in ape habitat due to the risk of fire and of disease transmission via contaminated cigarette butts. The smell of smoke may also scare wildlife.

Nose blowing and spitting on the ground are not allowed. Staff and tourists should use handkerchiefs or tissues as needed and ensure they are disposed of appropriately, as with masks, and away from the apes.

The same boots and clothing should not be worn to visit more than one group of apes, by staff or visitors, unless they have been washed and dried between visits.

\section{Prevent contamination of the habitat with food waste}

Eating and drinking are not allowed during visits. Food and drink must not be visible while observing great apes, and should be left with porters or other personnel who remain out of sensory range of the apes. Food must not be consumed within $500 \mathrm{~m}$ of apes. Food waste and all other rubbish must be stowed in backpacks and carried out of the forest to prevent deposition of infectious waste in the habitat. This will minimize accidental contaminated waste and prevent the apes from developing an association between humans and food.

Food must never be used to attract apes toward tourists.

\section{Tipping policies and staff salaries}

Tourists should be informed that tips and gifts cannot be used to encourage staff to break regulations, and staff must not view tips as justification to ignore regulations. Both infractions also reduce the professionalism of the operation. Tipping policies should be clearly displayed and explained so that tourists are aware of the issues before starting their activity. Tourists dislike having rules presented to them and then seeing them broken- This reduces respect for both staff and regulations. This message must be communicated to staff through education, training, and monitoring, to enhance their compliance. Regular monitoring and staff supervision should be used to reinforce tipping practices, and a no-tipping policy should be considered if tips are judged to be a prime factor in staff relaxing regulations.

All tourism staff, from check-in clerks to trackers and guides, should benefit from tips via a shared tip box with tips distributed equally among all staff each day. Policies specifying that pooled tips will be divided among all tourism staff will help prevent irregularities and should be posted where they are visible to visitors.

Tourism staff should be paid satisfactory salaries (at least a "living wage" and preferably higher) to minimize temptations to violate regulations for higher tips.

\section{Monitoring and enforcement of rules}

It is imperative that all staff understand the rules, can explain their rationale to visitors, and can enforce them. Therefore, tourism staff should be regularly monitored and evaluated on their conduct, and results should be discussed openly between evaluators and staff. Regular refresher courses reinforce staff understanding and 
adherence to tourism regulations and should include training on enforcement techniques.

A post-visit checklist provided to tourists and staff could help to reinforce staff compliance, and specific cases where staff had problems enforcing rules could be used in staff training exercises.

\section{Site management}

\section{Infrastructure designed to minimize impact on apes and habitat}

Environmental Impact Assessments should be carried out for all tourism-related infrastructure developments, in keeping with national environmental legislation. Tourism infrastructure, such as lodges, campsites, and visitor centers, should be constructed in areas where impacts on apes and their habitats are minimal. If possible, tourism infrastructure should be located far enough outside ape habitat to prevent acces $\Omega$ t tny disruption to native vegetation, especially forest, should be kept to a minn.

Tourism infrastructure should not be built in areas frequented by apes, due to risks of encountering people, food preparation areas, waste disposal, or sanitation facilities, and risk of injury from electrical cables or other hazards (Figure 17.2). If infrastructure on any scale is necessary in ape habitat, attention should be paid to reducing the impact of tree felling on the apes' feeding and ranging requirements (see Morgan \& Sanz, 2007). Tourism infrastructure should not include installations that could attract apes, such as the planting of crops or fruit trees.

Tourism infrastructure must not introduce additional disease risks to ape populations. Attention to appropriate sanitation, hygiene, and waste disposal is critical in this regard.

\section{Staff housing and administrative infrastructure}

Staff and administrative buildings should be sited to maximize the oversight and control of tourism programs. These buildings must be located and designed to minimize impacts on apes and their habitat from noise and other hazards (e.g. fuel, power lines, toxins). Managers and law-enforcement teams should be posted on-site so that monitoring and protection activities can be carried out routinely.

\section{Tourism accommodation should benefit local communities}

Accommodation in lodges or campsites should be managed to maximize community benefits through community ownership, employment opportunities, or revenue-sharing schemes that provide income to members of the community or funding for social services. 


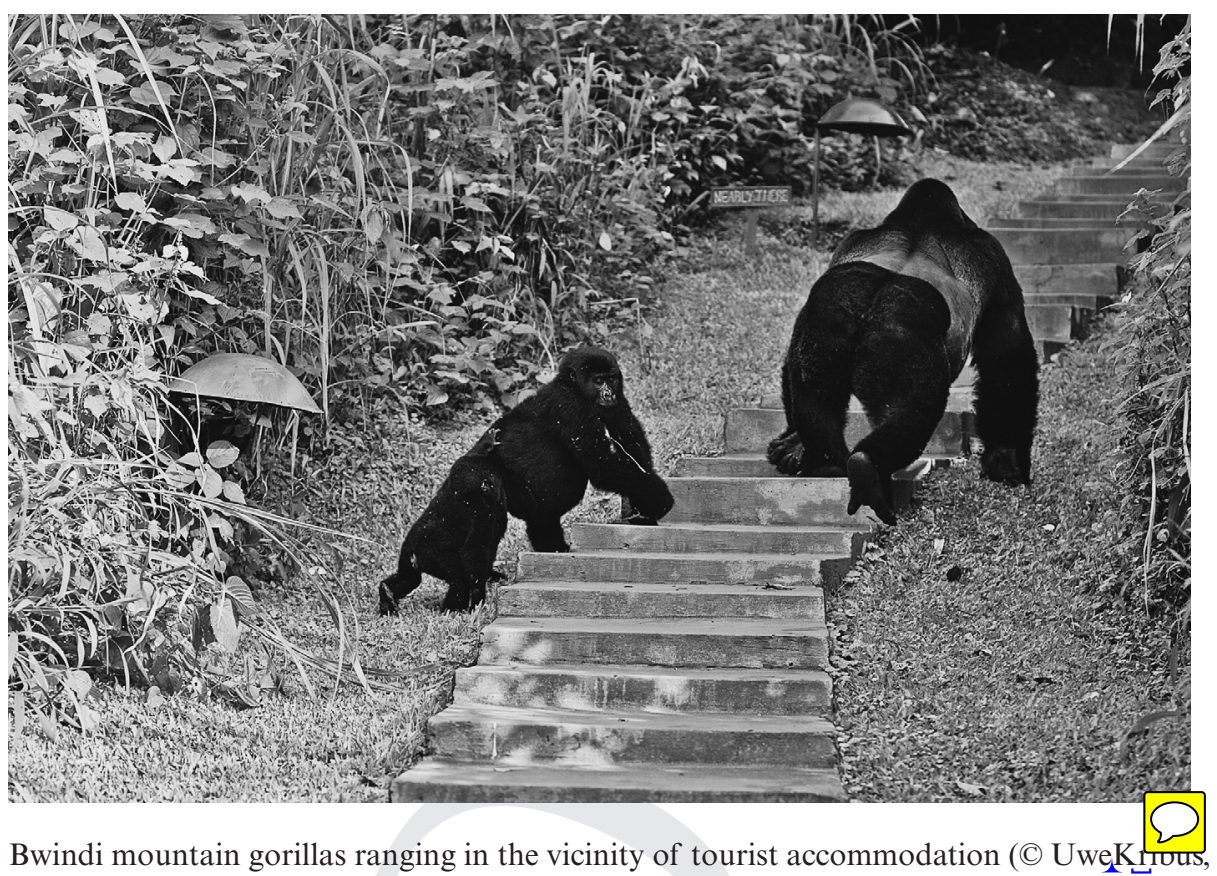

Figure 17.2. Bwindi mountain gorillas ranging in the vicinity of tourist accommodation ( UweKHurs, Uganda)-

Tourist accommodation that benefits local communities should be protected from external competition. This can be achieved through zoning that limits the number of facilities allowed to operate at preferred locations.

\section{Special considerations for small and eritically endangered populations}

Particular caution is required before developing or expanding tourism with Critically Endangered taxa. This classification is given to three of the four gorilla subspecies (mountain, western lowland, and Cross River) and the Sumatran orangutan (IUCN, 2013). Although the three subspecies of Bornean Orangutan are listed as Endangered, the northwestern subspecies and the East Kalimantan populations of the eastern subspecies also merit special consideration because their remaining populations are similar in size to those of the Sumatran orangutan (Soehartono et al., 2007). Special consideration is also merited for Grauer's gorillas, as they live in a volatile region and over the last 20 years their numbers have been drastically reduced (Maldonado et al., 2012).

\section{Risk-management programs}

IUCN guidelines recommend that a number of impact-management measures accompany all great ape tourism programs. Additionally, funding for risk 
management must be guaranteed before any tourism activities are launched with small or Critically Endangered populations, to ensure that negative impacts are identified and immediately addressed.

\section{Optimize before expanding}

A number of sites with Critically Endangered great apes are already conducting tourism. In some of them, tourism has made a positive contribution, generating income for comprehensive conservation programs in and around ape habitat (Gray \& Rutagarama, 2011; Plumptre \& Williamson, 2001; Robbins et al., 2011; Williamson \& Fawcett, 2008). Income to national treasuries and a range of stakeholders has resulted in enhanced perceptions of great apes and stimulated long-term support for great ape conservation (Plumptre \& Williamson, 2001; Williamson \& Fawcett, 2008). While keeping these successes in mind, it is important to step back and evaluate the future of tourism at these sites, to protect the programs from complacency and to prevent them from sliding toward overexploitation of the apes. There has been a general tendency to expand tourism by habituating additional animals (Macfie, 2007), but for conservation to remain the primary objective, it is important to resist the temptation to expand for economic gain. Economic benefits can be achieved in ways that do not involve subjecting the apes to additional tourists or exposing more individuals to tourism. The recommendations below should be followed at all sites operating tourism with Critically Endangered apes.

\section{Encourage income generation that does not involve great ape tourism expansion}

Governments and conservation authorities should encourage alternative means of stimulating earnings by authorities, the private sector and local economies, such as investment in national enterprise development, micro-credit schemes for local enterprises, and support for other business developments.

Do not increase the number of great ape groups habituated for tourism

Sites with Critically Endangered great apes should avoid increasing the number of habituated groups or individuals. It is important to maintain a balance of exposed and unexposed groups to better mitigate negative impacts of tourism.

\section{Limit the number of individual great apes habituated for tourism}

Habituation decisions should not be based on habituating the largest groups of apes, or the greatest number of individuals, for tourism. Habituation decisions must include consideration of maintaining a significant proportion of the population as unexposed to tourism, as the larger the proportion that is exposed to tourism, the greater the risk that disease could result in drastic reduction of the population. 


\section{Maximize revenue per tourism permit}

If there is pressure to increase revenues from great ape tourism, the first measure to take should be to increase permit prices. Revenue per permit can also be maximized by diversifying tourism activities at each site and building ape tourism into national tourism circuits. Extending the average length of in-country stay of great ape tourists would increase the earnings associated with each permit at local, regional, and national levels.

\section{Monitoring and evaluation}

Tourism programs should be supported by independent impact assessments to inform and improve tourism policy and management systems. Formal mechanisms of review and incorporation of research results into management and policy will help ensure that conservation impacts are optimized.

\section{Applied research}

Tourism should stimulate the development of research programs to meet the requirements of tourism-impact monitoring and applied research. Research programs associated with great ape tourism should include the following $\overline{\bar{z}}_{\overline{2}}$

\section{Disease monitoring}

Disease is the most serious risk associated with great ape tourism. Regular health monitoring is needed to patterns of disease, allow management to design prevention measures (e.g. quarantine, tourist vaccination regulations, community health projects), and respond to disease outbreaks. Routine observations of touristvisited great apes by trained personnel and non-invasive screening should be supplemented by opportunistic sampling of animals that have had to be immobilized (IUCN guidelines are in preparation).

\section{Behavioral monitoring}

Tourism can have serious negative impacts on the behavior, physiology, and social dynamics of habituated great apes. Independent research on the behavior of great apes visited by tourists will highlight potential or incipient problems before they become severe and will allow corrective management (see Hodgkinson \& Cipolletta, 2009; Muyambi, 2005).

\section{Ecological monitoring}

Heavy tourist traffic may cause soil compaction, erosion, trampling, and damage to vegetation. Controls to minimize degradation of the habitat should include prohibition of cutting or removal of seedlings and vegetation, walking off trails, and fire. 
Regular ecological monitoring should be instituted to enable the improvement and enforcement of these controls.

Population monitoring

Population monitoring is an essential adjunct to tourism management; it serves as a longer-term indicator of the impact of tourism and other conservation interventions on great ape populations.

\section{Law-enforcement monitoring}

The development and operation of tourism must not divert attention and resources away from the central goal of protecting great apes and their habitat. It is, therefore, important to monitor trends in illegal activities and assess the performance and results of law-enforcement activities. Law-enforcement monitoring will highlight areas for improvement or the need for increased surveillance, and can inform management when apes are ranging into areas of illegal activity, so that prevention and response to those activities can be enhanced.

\section{Conflict monitoring}

Human-great ape conflicts can be alleviated through the provision of tourism benefits to local communities, or exacerbated by tourism altering the apes' ranging behavior and bringing them into conflict situations more frequently. It is important that conflicts are systematically monitored and the success of mitigation efforts measured.

\section{Economic assessments}

The motivation for initiating great ape tourism is often the economic benefits anticipated by various institutional, local, and national stakeholders, in both the public and private sectors. However, as stated throughout this document, conservation must be the ultimate goal of great ape tourism and should be given priority over all other interests, especially economic ones. Therefore, it is important to monitor the economic impacts of great ape tourism to centinue to assess whether its continuing operation is justified and to inform management decisions, such as pricing structures and booking systems. Methodology can be adapted from previous studies (e.g. Hatfield \& Malleret-King, 2006; WCS Gabon, 2008; Wilkie \& Carpenter, 1999).

\section{Program monitoring and evaluation}

\section{Financial monitoring and transparency}

Insofar as tourism is a tool to provide funding for conservation, it is crucial that systems are in place to monitor tourism revenue generation and distribution. Financial controllers must be able to demonstrate that income is supporting great ape conservation, protected area management and operations, community projects, and revenue-sharing programs. Transparency will go a long way to reassuring 
critics of great ape tourism that this is an appropriate and effective conservation measure.

\section{Program reporting}

Progress reports and the results of tourism-impact monitoring and applied research should be produced at regular intervals (preferably quarterly, but at least annually) to stimulate internal review and timely identification of issues to be addressed.

\section{Program evaluation}

Regular medium-term (every two years) internal assessments of the performance, management, and impacts of great ape tourism programs must be carried out to accurately monitor progress and to allow for program review and improvement. The results of management-related research (see "Applied research") should be used to guide improvement and adaptation in tourism program management. In the longer term, external evaluations should take place every five years to ensure appropriate implementation and to foster learning and exchange with other great ape tourism sites.

\section{Staff monitoring}

Staff working in great ape tourism must be fully supported in their role as the prime defenders of great apes against the negative impacts of tourism. They need to be, and feel, able to discuss and enforce tourism rules and regulations. Their roles must be evaluated regularly to assess effectiveness and modify management, as needed. This can be achieved by regular supervision, including evaluation in the field, evaluation during tourism-impact research, and feedback from tourists.

\section{Conclusions and guiding principles for using tourism as a great ape conservation tool}

These guidelines were developed not only for conservation practitioners, but also for development organizations, donors, and private companies promoting tourism development in great ape habitat. The general principle that determined the orientation of these guidelines is that first and foremost, tourism must contribute to the conservation of great apes in their natural habitat. Additionally, tourism programs should be designed to support other activities such as law enforcement, habitat protection, and community involvement in conservation.

A number of biological, geographical, economic, and global factors will determine the success or failure of a great ape tourism project, for example, the failure of the tourism market to provide revenue sufficient to cover development and operating costs or the failure to protect the great apes from the negative impacts inherent in tourism. Once apes are habituated to human observers, they are permanently at increased risk from poaching and other forms of conflict with humans. Therefore, they must be protected in perpetuity even if tourism fails or ceases for any reason. 
Great ape tourism should not be developed without conducting critical feasibility analyses to ensure that there is sufficient potential for success. Strict attention must be paid to the design of the enterprise, its implementation, and its continual management capacity in a manner that avoids, or at least minimizes, the negative impacts of tourism on local communities and on the apes themselves. Monitoring programs to track costs and impacts, as well as benefits, are essential to inform management on how to optimize tourism for conservation benefits.

\section{Nine guiding principles}

Tourism is not a panacea for great ape conservation or revenue generation

Tourism can contribute to great ape conservation but will not be viable at all sites: sites that do not meet the criteria listed in IUCN guidelines are not appropriate for great ape tourism. Sites that fail to generate the revenue anticipated may suffer a backlash against the conservation effort, so care must be taken to avoid raising false expectations among politicians, managers. and local communities.

\section{Great ape tourism must be based on sound objective science}

Great ape tourism can be controversial and not all conservationists agree that it is an acceptable activity. To defend great ape tourism as a sustainable component of a conservation strategy, in addition to the requirement that conservation must take priority over economic and political interests, decisions affecting tourism must be based on sound and objective science and regulations governing visits must be scientifically formulated and rigorously enforced.

\section{Comprehensive understanding of impacts must guide tourism development}

Great ape tourism has a number of advantages and disadvantages, all of which must be clearly understood by everyone involved in the planning and implementation. These issues should be kept in mind at all stages of the design, development, and management of great ape tourism. The guidelines in this document are founded on the principle of optimizing conservation impacts for great apes and their habitats. Any site that cannot sustain impact-optimizing activities, financially or institutionally, should not initiate a great ape tourism program.

\section{Conservation benefits must significantly outweigh risks}

Great ape tourism development proposals should undergo full feasibility and impact assessments, and should not be implemented unless the benefits anticipated outweigh the potential risks. Tourism and its associated impact mitigation measures must significantly improve the conservation outcome compared to a no-tourism scenario. Only programs that will enhance conservation efforts and improve protection of the resident great ape population should go ahead. While this is a general guideline for all great apes, it is crucial for Critically Endangered and small populations due to their precarious conservation status. 
Conservation investment and action must be assured in perpetuity

Anti-poaching activities must be launched in parallel with habituation efforts, especially in areas where poaching of great apes is high (e.g. Central Africa where poaching for is at its highest levels, and Southeast Asia where poaching for the pet trade is high). Once habituated, great apes and their home ranges must be protected and monitored daily by law-enforcement teams with on-call veterinary expertise. These activities are necessary not only for conservation, but also to support tourism development and management, and must be continued in perpetuity to protect great apes that have been habituated, and to ensure the viability of a tourism enterprise. Financial contingency plans to ensure that conservation actions continue during periods of low tourism should be in place before tourism is developed.

\section{Benefits and profit for local communities should be maximized}

For great ape tourism to properly meet the criteria for sustainable tourism, it must maximize both direct and indirect benefits to adjacent communities that bear the costs of conservation, including opportunity costs (Grosspietsch, 2007). While conservation must take priority over other interests, tourism should strive to contribute to poverty reduction wherever possible and, at the very least, should do no harm to local communities (SGLCP, 2009). Direct benefits include local recruitment of tourism staff and sharing a percentage of tourism revenue with adjacent communities. Indirect benefits include marketing and support for services that earn additional income for communities (such as tourism infrastructure which is partially or wholly community owned and operated). Care should be taken to ensure that benefits are not focused on a small section of a community but are accessible to the majority. Full consultations should be conducted to ensure that benefits are provided in a manner both recognized and valued by local residents. Guidance on involving communities in tourism activities is available (e.g. Ancrenaz et al., 2007; Gutierrez et al., 2005; Rajaratnam et $a l$, ,2008), as are lessons learned through the development and implementation of revenue-sharing and other community programs centered on great ape tourism (Adams \& Infield, 2003; Archabald \& Naughton-Treves, 2001; Blomley et al., 2010).

\section{Profit to private sector partners must not be a driving force}

In the development of any great ape tourism activity, conservation principles must take precedence over profit generation for private sector stakeholders. While a successful tourism program will provide opportunities for income to accrue at various levels, the primary aim of developing and operating this revenue-generating mechanism is to support the cost of conservation efforts. The needs of communities living in or adjacent to ape habitats must also be a high priority concern. If the priorities become inverted, with profit to the private sector becoming the driving force behind great ape tourism, then stakeholders must analyze how the priorities could have gone astray and how to rebalance them. 


\section{Tourism can enhance long-term support for conservation}

Tourism can be used to enhance the financial, esthetic, and cultural value, of great apes and their habitats as perceived by local communities, policy-makers, and political leaders, thereby promoting long-term support for conservation of apes and their habitats.

\section{Conservation must be the primary goal of great ape tourism}

Conservation must be given priority over economic and political concerns at all great ape tourism sites. Any site that undertakes great ape tourism must place continued and enhanced emphasis on protection, law enforcement, environmental awareness-raising, and other conservation activities. The effort and resources required to develop and operate tourism should not divert resources and attention away from the conservation focus.

In closing, readers are urged to adhere to the guiding principles of best practice in great ape tourism, and to keep them in mind at all stages of planning, developing, implementing, and monitoring great ape tourism.

\section{Acknowledgments}

We wish to thank Anne E. Russon and Janette Wallis for the invitation to contribute to this volume. We also thank the following for contributing to IUCN tourism guidelines: Marc Ancrenaz, Chloe Cipolletta, Debby Cox, Christina Ellis, David Greer, Chloe Hodgkinson, Anne Russon, and Ian Singleton.

\section{References}

Adams, W. M. and Infield, M. (2003). Who is on the gorillas' payroll? Claims on tourist revenue from a Ugandan national park. World Development, 31: 177-190.

Ancrenaz, M., Dabek, L., and O’Neil, S. (2007). The costs of exclusion: recognizing a role for local communities in biodiversity conservation. PLoS Biology, 5: e289.

Archabald, K. and Naughton-Treves, L. (2001). Tourism revenue-sharing around national parks in Western Uganda: early efforts to identify and reward local communities. Environmental Conservation, 28: 135-149.

Blomley, T., Namara, A., McNeilage, A., et al. (2010). Development AND Gorillas? Assessing Fifteen Years of Integrated Conservation and Development in South-western Uganda. Natural Resource Series No. 23. London and Edinburgh, UK: International Institute for Environment and Development (IIED).

GRASP. (2006). The Kinshasa Declaration. Great Ape Survival Partnership, Nairobi. URL: www.unesco.org/mab/doc/grasp/E_KinshasaDeclaration.pdf (accessed Apr. 4, 2014).

Gray, M. and Rutagarama, E. (eds.) (2011). 20 Years of IGCP: Lessons Learned in Mountain Gorilla Conservation. Kigali, Rwanda: International Gorilla Conservation Programme.

Grosspietsch, M. (2007). Maximizing Tourism's Contribution to Poverty Reduction in Rwanda. Doctoral dissertation, Westphalian Wilhelms-University, Münster, Germany. 
Gutierrez, E., Lamoreux, K., Matus, S., and Sebunya, K. (2005). Linking Communities, Tourism and Conservation: A Tourism Assessment Process. Washington, DC: Conservation International and The George Washington University.

Hatfield, R. and Malleret-King, D. (2006). The Economic Value of the Mountain Gorilla Protected Forests (The Virungas and Bwindi Impenetrable National Park). Nairobi: International Gorilla Conservation Programme (IGCP).

Hodgkinson, C. and Cipolletta, C. (2009). Western lowland gorilla tourism: impact on gorilla behaviour. Gorilla Journal, 38: 29-32.

Homsy, J. (1999). Ape Tourism and Human Diseases: How Close Should We Get? A Critical Review of Rules and Regulations Governing Park Management and Tourism for the Wild Mountain Gorilla, Gorilla gorilla beringei. Nairobi: International Gorilla Conservation Programme (IGCP). www.igcp.org/wp-content/themes/igcp/docs/pdf/homsy_rev.pdf (accessed Apr. 4, 2014).

IUCN (2013). The IUCN Red List of Threatened Species. Version 2013.2. Gland, Switzerland and Cambridge, UK: International Union for Conservation of Nature. www.iucnredlist. org (accessed Apr. 4, 2014).

Klailova, M., Hodgkinson, C., and Lee, P. C. (2010). Behavioral responses of one western lowland gorilla (Gorilla gorilla gorilla) group at Bai Hokou, Central African Republic, to tourists, researchers and trackers. American Journal of Primatology, 71:1 10.

Leroy, E. M., Kumulungui B., Pourrut X., et al. (2005). Fruit bats as reservoirs of Ebola virus. Nature, 438: 575-576.

Macfie, E. J. (2007). Habituation Impact Assessment: A Tool for the Analysis of Costs and Benefits Related to the Potential Habituation of a Gorilla Group for Either Tourism or Research. Unpublished report to the Virunga Bwindi Gorilla Management Technical Advisory Committee, International Gorilla Conservation Programme, Nairobi.

Macfie, E. J. and Williamson, E. A. (2010). Best Practice Guidelines for Great Ape Tourism. Gland, Switzerland: IUCN/SSC Primate Specialist Group. www.primate-sg.org/best_ practice_tourism (accessed Apr. 4, 2014).

Maldonado, O., Aveling, C., Cox, D., et al. (2012). Grauer's Gorillas and Chimpanzees in Eastern Democratic Republic of Congo (Kahuzi-Biega, Maiko, Tayna and Itombwe Landscape): Conservation Action Plan 2012-2022. Gland, Switzerland: IUCN/SSC Primate Specialist Group, Ministry of Environment, Nature Conservation and Tourism, Institut Congolais pour la Conservation de la Nature, and the Jane Goodall Institute.

Morgan, D. and Sanz, C. (2007). Best Practice Guidelines for Reducing the Impact of Commercial Logging on Great Apes in Western Equatorial Africa. Gland, Switzerland: IUCN/SSC Primate Specialist Group. www.primate-sg.org/best_practice_logging (accessed Apr. 4, 2014).

Muehlenbein, M. P. and Ancrenaz, M. (2009). Minimizing pathogen transmission at primate ecotourism destinations: the need for input from travel medicine. Journal of Travel Medicine, 16: 229-232.

Muehlenbein, M. P., Martinez, L. A., Lemke, A. A., et al. (2008). Perceived vaccination status in ecotourists and risks of anthropozoonoses. EcoHealth, 5: 371-378.

Muyambi, F. (2005). The impact of tourism on the behaviour of mountain gorillas. Gorilla Journal, 30: 14-15.

Palacios, G., Lowenstine, L. J., Cranfield, M. R., et al. (2011). Human metapneumovirus infection in wild mountain gorillas, Rwanda. Emerging Infectious Diseases, 17: 711-713.

Plumptre, A. J. and Williamson, E. A. (2001). Conservation-oriented research in the Virunga region. In: M. M. Robbins, P. Sicotte, and K. J. Stewart (eds.), Mountain Gorillas: Three 
Decades of Research at Karisoke. Cambridge, UK: Cambridge University Press, pp. 361-390.

Rajaratnam, R., Pang, C., and Lackman-Ancrenaz, I. (2008). Ecotourism and indigenous communities: the Lower Kinabatangan experience. In: J. Connell and B. Rugendyke (eds.), Tourism at the Grassroots: Villagers and Visitors in the Asia Pacific. London, UK: Routledge, pp. 236-255.

Robbins, M. M., Gray, M., Fawcett, K. A., et al. (2011). Extreme conservation leads to recovery of the Virunga mountain gorillas. PLoS One, 6: e19788. doi:10.1371/journal. pone.0019788.

Ryan, S. J. and Walsh, P. D. (2011). Consequences of non-intervention for infectious disease in African great apes. PLoS One, 6: e29030. doi:10.1371/journal.pone.0029030.

Sandbrook, C. G. and Semple, S. (2006). The rules and the reality of mountain gorilla (Gorilla beringei beringei) tracking: how close do tourists get? Oryx, 40: 428-433.

SGLCP. (2009). Response to Notification: Updating or Revision of the Convention after 2010. Convention on Biological Diversity (CBD) Steering Group on Linking Conservation and Poverty (SGLCP). www.cbd.int/doc/strategic-plan/revision-input/Germany.pdf (accessed Apr. 4, 2014).

Soehartono, T., Susilo, H. D., Andayani, N., et al. (2007). Orangutan Indonesia: Conservation Strategies and Action Plan 2007-2107. Jakarta, Indonesia: Directorate General of Forest Protection and Nature Conservation, Ministry of Forestry of the Republic of Indonesia. www.primate-sg.org/action_plans/ (accessed Apr. 4, 2014).

Timen, A., Koopmans, M. P. G., Vosson, A. C. T. M., et al. (2009). Response to imported case of Marburg hemorrhagic fever, the Netherlands. Emerging Infectious Diseases, 15: 1171-1175.

WCS Gabon. (2008). Langoué Bai, Ivindo National Park: Review of the Pilot Tourism project 2001-June 2008. Libreville, Gabon: Wildlife Conservation Society. http://en.calameo.com/ books/00000278504447bd38612 (accessed Apr. 4, 2014).

Weber, A. W. (1993). Primate conservation and eco-tourism in Africa. In: C. S. Potter, J. I. Cohen, and D. Janczewski (eds.), Perspectives on Biodiversity: Case Studies of Genetic Resource Conservation and Development. Washington, DC: American Association for the Advancement of Science Press, pp. 129-150.

Wilkie, D. S. and Carpenter, J. F. (1999). Can tourism finance protected areas in the Congo Basin. Oryx, 33: 332-338.

Williamson, E. A. and Fawcett, K. A. (2008). Long-term research and conservation of the Virunga mountain gorillas. In: R. Wrangham and E. Ross (eds.), Science and Conservation in African Forests: The Benefits of Longterm Research. Cambridge, UK: Cambridge University Press, pp. 213-229. 